\title{
ERGONOMIC ORIENTED WORKING METHOD IN THE PROCESS OF WIPING CANS OF SARDINES INCREASED PRODUCTIVITY AND INCOME OF WORKERS PT. BMP NEGARA, BALI
}

\author{
Ni Luh Gede Aris Maytadewi Negara 1, Luh Made Indah Sri Handari Adiputra ${ }^{*}{ }^{\star 凶}$,
} I Dewa Putu Sutjana ${ }^{3}$

${ }^{1}$ Occupational, Health and Safety Bachelor Programme, International Bali University, Indonesia *2, 3 Physiology Department, School of Medicine Udayana University, Indonesia

DOI: https://doi.org/10.29121/IJOEST.v4.i5.2020.102

Article Type: Research Article

Article Citation: Ni Luh Gede Aris Maytadewi Negara, Luh Made Indah Sri Handari Adiputra, and

I Dewa Putu Sutjana (2020).

ERGONOMIC ORIENTED WORKING

METHOD IN THE PROCESS OF

WIPING CANS OF SARDINES

INCREASED PRODUCTIVITY AND

INCOME OF WORKERS PT. BMP

NEGARA, BALI. International

Journal of Engineering Science

Technologies, 4(5), 74-79.

https://doi.org/10.29121/IJOEST.v

4.i5.2020.102

Received Date: 15 August 2020

Accepted Date: 10 October 2020

\section{Keywords:}

Ergonomic Oriented Working

Method

Ergonomic Un-oriented Working

Method

Productivity

Income of Workers

Process of Wiping

Cans of Sardines

\section{ABSTRACT}

Motivation/Background: Productivity improvement is one of the important goals that need to be done by a company, including fish canning industry. High productivity can be achieved with the appropriate working method. This study was conducted to find out whether ergonomic oriented working method in sardine cans wiping process increasing productivity and income of workers in PT. BMP Negara compared than ergonomic unoriented working method.

Method: This study was experimental study with design two periods cross over pre and posttest group. Number of sample was 18 workers. This study was done at PT. BMP Negara, Jembrana Regency, Bali Province in December 2016. There are two different working method applied in the process of wiping cans of sardines, called ergonomic un-oriented working method and ergonomic oriented working method. Data collected was productivity and workers income. Those datas were compared and tested statistically, using Wilcoxon signed rank test.

Results: The result showed that the ergonomic oriented working method increased productivities about $34.43 \%(\mathrm{p}<0.05)$ and increased the income of workers as much as $31.51 \%(\mathrm{p}<0.05)$.

Conclusions: It could be concluded that ergonomic oriented working method in the process of wiping cans of sardines increased productivity and income of workers in PT.BMP Negara.

\section{INTRODUCTION}

PT. BMP Negara is a company engaged in fish canning industry with products such as sardines, mackerel and tuna [1]. Sardines making consists of several processes, beginning with the acceptance of raw materials, storage,

(C) 2020 The Author(s). This is an open access article distributed under the terms of the Creative Commons Attribution License, which permits unrestricted use, distribution, and reproduction in any medium, provided the original author and source are credited. 
cutting, washing, cans filling, steaming, slicing, sauce filling, cans closing, cans washing, sterilization, insulation, wiping, labeling and packaging, storage, deliviring [2]. The process of wiping is done before the cans are packed into the cardboard, with the aim that the sardine cans are not dirty, oily or dusty. After the can is clean, then the packing process is put the sardine can into the cardboard. One cardboard consists of 24 can, each can is weighs 425 grams. The worker at wiping process works in a standing position from 8 am until $4 \mathrm{pm}$, with one hour break time at $12 \mathrm{pm}$.

Working method at wiping process is to wipe the sardine can as much as possible and then pile up at random, then put and arranged into the cardboard. This working method is called ergonomic un-oriented working method. During the process, workers takes longer time to arrange the cans until completed. The other working method is put the can one by one and arranged into the cardboard after wiped. This working method is called ergonomic oriented working method. During the process, workers required shorter time because workers directly organize cans into cardboard in accordance with company rules.

From a preliminary study was found that production in the wiping section decreased on the first day of work (Monday) and two days before the holiday (Friday and Saturday). The average production for one week is 686 cartons/person, with an average income 344,662 IDR/week/person. The production results per hour have decreased at $10 \mathrm{am}, 12 \mathrm{am}$ and $4 \mathrm{pm}$.

Selection of the right working methods can improve productivity and safety, lower unit costs so as to enable more quality goods and services to be produced for more people. Also, can simplify jobs that may affect complaints during work such as fatigue, musculoskeletal complaints experienced by workers [3].

The ergonomic oriented working method in process of wiping cans of sardines possibly save working time than the ergonomic un-oriented working method. The sardines cans wiped by workers are different for the upper sides and down sides, when workers using ergonomic un-oriented working method, the process of arranging would takes more time. Workers need more time to put and positioned the cans into cardboard so that the composition of the entire can in a cardboard arranged according to company rules. Unlike the other working method, working using ergonomic un-oriented working method, worker need shorter time because workers directly arranges cans into a cardboard box after wiped the sardines cans.

Therefore, it is necessary to do research in an effort to overcome the problems that arise. Participation approach to the workers and the company suggested that the research hypotheses chosen is to compare the working method that already exist and done at the wiping section. This research goals was to find out the productivity and income of workers in wiping section PT.BMP Negara when used ergonomic oriented working method, and to find out the productivity and income of workers in wiping section PT.BMP Negara when used ergonomic un-oriented working method, and to find out which one is give the best productivity and income of workers in wiping section PT.BMP Negara when it is compared

\section{MATERIALS AND METHODS}

This study was experimental study with design two periods cross over pre and post test group. The populations in this study were the workers in the wiping section PT.BMP Negara. Sample determination technique is use simple random sampling technique with lottery method. The number of total sample was 18 people. Characteristics sample are : 1) female, 2) physically and mentally healthy, 3) age range 20-40 years, 4) minimum one year experience working in the process of wiping sardines, and 5) willing to be research subjects by signing an informed consent.

The working method is the work done by each of the sardine can workers. Ergonomic un-oriented work methods is a method of wiping the cans of sardines as much as possible and then stacked at random, after some times it is inserted and arranged into cardboard. Ergonomic oriented work method is a method of wiping the cans of sardines one by one and then insert and arranged into cardboard.

Work productivity is a comparison between the output with input per unit time. The type of data obtained is ratio scale. In this study productivity is calculated based on formulas

as follows:

Work Productivity $(\mathrm{P})=$

$$
\text { Out put (O) }
$$

$$
\text { Input (I) x Time (T) }
$$


Ergonomic Oriented Working Method in The Process of Wiping Cans of Sardines Increased Productivity and Income of Workers Pt. Bmp Negara, Bali

The indicators used to calculate work productivity are:

- Output: average number of cans that have been wiped.

- Input: energy released during work wiping measured from the pulse of work with using the 10-pulse method.

- Time: the time needed to complete the work wipe the sardine cans in time.

Income is a wage calculated based on the number of cans of sardines in one cardboard multiplied by the cardboard wage. Type of data obtained is ratio scale data.

The data that has been obtained is then processed and analyzed using a computer with the SPSS program version 20 for Windows. Data collected was productivity and workers income. Those datas were compared and tested statistically, using Wilcoxon signed rank test.

\section{RESULTS AND DISCUSSIONS}

Description of workers characteristics are presented in Table 1.

Table 1: Means (standar deviations) for sample characteristics sample ( $\mathrm{n}=18)$

\begin{tabular}{|c|c|}
\hline Characteristic sample & Mean (standar deviations) \\
\hline Age (year) & $32.27(5.84)$ \\
\hline Weight $(\mathrm{kg})$ & $58.05(6.46)$ \\
\hline Height $(\mathrm{cm})$ & $154.89(3.96)$ \\
\hline IMT $\left(\mathrm{kg} / \mathrm{m}^{2}\right)$ & $24.16(2.23)$ \\
\hline Working experience (year) & $7.44(2.00)$ \\
\hline
\end{tabular}

The average age of the subjects in this study was $32.27 \pm 5.84$ years, body weight was $58.05 \pm 6.46 \mathrm{~kg}$, body height was $154.89 \pm 3.96 \mathrm{~cm}$, BMI was $24.16 \pm 2.23 \mathrm{~kg} / \mathrm{m} 2$ and working experience was $7.44+2.00$ years. The age, weight, height, and BMI included in the normal category whereas the subject's work experience included in the category experienced.

A description of the characteristics of the working environment is presented in Table 2.

Table 2: Means (standar deviations) for working environtment characteristics

\begin{tabular}{|c|c|c|}
\hline Working environtment characteristics & $\begin{array}{c}\text { 1st Period } \\
\text { Mean (Standar deviations) }\end{array}$ & $\begin{array}{c}\text { 2nd Period } \\
\text { Mean (Standar deviations) }\end{array}$ \\
\hline & $29.50(1.29)$ & $29.83(1.46)$ \\
Dry temperature $\left({ }^{\circ} \mathrm{C}\right)$ & $25.61(0.69)$ & $25.55(0.61)$ \\
Wet temperature $\left({ }^{\circ} \mathrm{C}\right)$ & $86.84(2.98)$ & $85.74(3.10)$ \\
Relative humidity (\%) & $0.05(0.01)$ & $0.04(0.01)$ \\
Air velocity (m/s) & $372.94(27.79)$ & $367.50(23.87)$ \\
Light intensity (Lux) & $89.22(3.42)$ & $89.11(2.74)$ \\
Noise (dB) & & \\
\hline
\end{tabular}

The average dry temperature for 1 st Period was $29.50 \pm 1.29^{\circ} \mathrm{C}$, while 2 nd Period was $29.83 \pm 1.46^{\circ} \mathrm{C}$. The average wet temperature in 1 st Period was $25.61 \pm 0.69^{\circ} \mathrm{C}$, while 2 nd Period was $25.55 \pm 0.61^{\circ} \mathrm{C}$. Dry temperature and wet temperature are used to determine relative humidity in the psychometric table, so the average relative humidity for 1 st Period was $86,84 \pm 2,98 \%$, while 2 nd Period was $85,74 \pm 3,10 \%$. Air velocity in 1 st Period was 0.05 $\pm 0.01 \mathrm{~m} / \mathrm{s}$ while $2 \mathrm{nd}$ Period was $0.04 \pm 0.01 \mathrm{~m} / \mathrm{s}$. The light intensity in 1 st Period was $372.94 \pm 27.79$ lux while the 2nd Period was $367.50 \pm 23.87$ lux. The noise in 1st Period was $89.22 \pm 3.43 \mathrm{~dB}$, while 2 nd Period was $89.11 \pm 2.74$ $\mathrm{dB}$.

An analysis of productivity is presented in Table 3. 
Ni Luh Gede Aris Maytadewi Negara, Luh Made Indah Sri Handari Adiputra, and I Dewa Putu Sutjana

Table 3: Productivity analysis

\begin{tabular}{|c|c|c|c|c|c|c|}
\hline Variable & $\mathrm{n}$ & $\begin{array}{c}\text { Ergonomic un-oriented } \\
\text { working method }\end{array}$ & $\begin{array}{c}\text { Ergonomic oriented } \\
\text { working method }\end{array}$ & $\begin{array}{c}\text { Mean } \\
\text { difference }\end{array}$ & $\begin{array}{c}\mathrm{t} \\
\text { value }\end{array}$ & $\begin{array}{c}\mathrm{p} \\
\text { value }\end{array}$ \\
\cline { 2 - 5 } & & Mean (SD) & Mean (SD) & 2.18 & -3.72 & 0.01 \\
\hline Productivity & 18 & $6.33(0.29)$ & $8.51(0.28)$ & $28)$ &
\end{tabular}

There is a significant difference in the worker's productivity when used ergonomic oriented working method and ergonomic un-oriented working method. There is a significant increase in productivity in groups using ergonomic oriented working method.

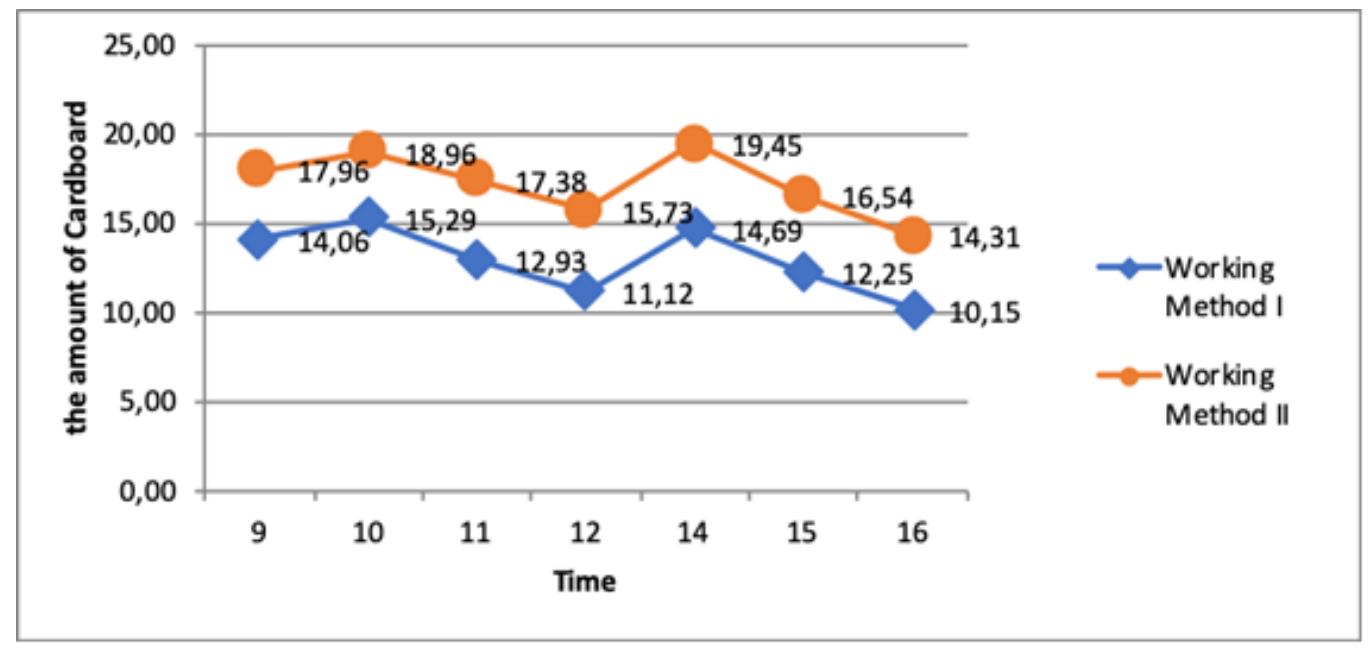

Figure 1: An average production results per hour per day

The production results of workers per hour is shown in Figure 1, the production results in the two groups of working methods decrease at 12 am and 4 pm. Production results for eight hours shown to be higher for workers with ergonomic oriented working method (working method II) compared than ergonomic un-oriented working method (working method I). Application of ergonomic oriented working method can increase the productivity of workers in the process of wiping cans of sardines. Increased productivity will be achieved if all components in work systems ergonomically designed [4]. Increased work productivity using ergonomic oriented working method becaused more production results with the same working time. An increasing in working time increased the speed and rhythm of work thereby increasing worker productivity and worker income.

The use of ergonomically oriented working methods by workers is proven to save working time so that the perceived fatigue of workers is lower than the ergonomically un-oriented working method. Sardine cans wiped by different workers for the upper and lower sides, when workers working using ergonomic un-oriented working method, when the process of organizing workers takes more time to position the cans so that the composition of all cans in a cardboard is arranged according to company rules. Unlike the case with working using ergonomic-oriented work methods, after the process of wiping the workers directly organize cans into the cardboard, so the work time is shorter. While working using a non-ergonomic-oriented working method of time required to wipe 1 can of sardine \pm 5.11 seconds, while using ergonomically oriented work methods \pm 3.86 seconds.

Recommendations of ergonomic interventions to increase work productivity are also widely recommended such as the work station design improves productivity by $20.29 \%$ [5], in line with research Sutjana in 2000 increased farmer productivity while working using ergonomically oriented tools (jagged sickle) [6], as well as improvements the station and the working environment of perapen in the nguwad process of augmented through the total ergonomic approach increase work productivity by 55.83\% [7]. The provision of floor chairs and the arrangement layout of the production process increased the productivity of the reed roofs making workers as much as $34.60 \%$. This showed that ergonomic working conditions and processes can increase productivity [8]. Another study also found that work posture more ergonomically increased work productivity in construction workers as much as 5.97\% [9]. Sari et al. found that 
improvement working conditions ergonomically increased work productivity of workers in the incense industry at UD. Manik Galih, Tabanan as much as 35.80\% [10].

Income analysis is presented in Table 4.

Table 4: Income analysis

\begin{tabular}{|c|c|c|c|c|c|c|}
\hline Variable & $\mathrm{n}$ & $\begin{array}{c}\text { Ergonomic un-oriented } \\
\text { working method }\end{array}$ & $\begin{array}{c}\text { Ergonomic oriented } \\
\text { working method }\end{array}$ & $\begin{array}{c}\text { Mean } \\
\text { difference }\end{array}$ & $\begin{array}{c}\mathrm{t} \\
\text { value }\end{array}$ & $\begin{array}{c}\mathrm{p} \\
\text { value }\end{array}$ \\
\cline { 3 - 6 } & $\mathrm{Mean}(\mathrm{SD})$ & Mean (SD) & $63,338.24(868,89)$ & $15,176.74$ & -3.72 & 0.01 \\
\hline $\begin{array}{c}\text { Income in } \\
\text { IDR }\end{array}$ & 18 & $48,161.50(791,42)$ & & & \\
\hline
\end{tabular}

Worker income data in this study were obtained from the production results is multiplied by the wage per cardboard (1 cardboard is pay for 517 IDR). The data obtained were analyzed with Wilcoxon signed rank test because the distibution data is not normal. The significance analysis for income in both working methods showed significantly different result $(\mathrm{p}<0.05)$ with $\mathrm{z}=-3.72$ and $\mathrm{p}$ value $=0.01$. There is a significant difference in the worker income when worker used ergonomic oriented working method and ergonomic un-oriented working method. A significant increase in workers income in worker when using ergonomic oriented working method.

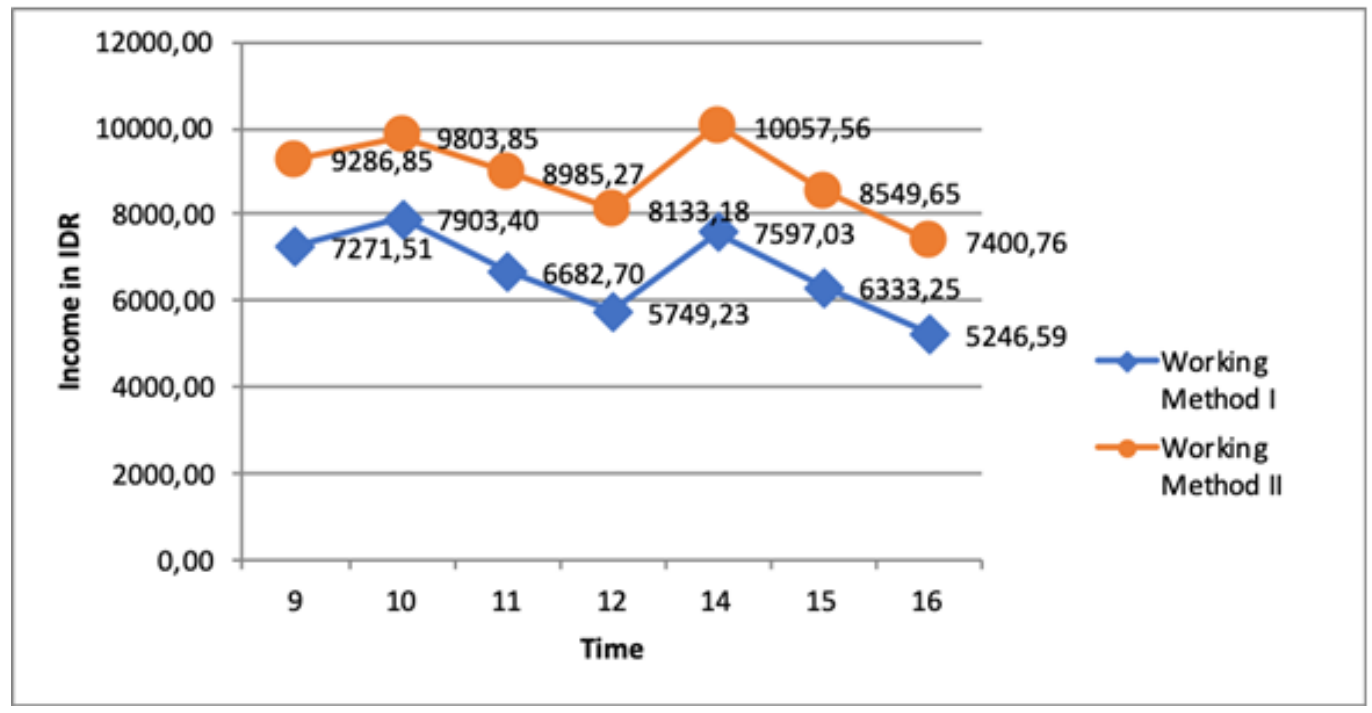

Figure 2: An average worker income per hour per day

The result from the time motion study shown the effective movement and the ineffective movement when the work process obtained data when working using work methods are not ergonomically oriented workers do ineffective movement as much as \pm 5 times per hour, while working using work-oriented method ergonomics Workers perform ineffective movement as much as \pm 2 times per hour. Ineffective movements are meant to sit on the sidelines of work time, scratching heads, wiping sweat, and talking among workers.

In this study increased income occurs when workers use ergonomic oriented working method as much as $31.51 \%$, because the work more so that the value of rupiah received higher. This is in accordance with the opinion of Suarbawa) states that the improvement of station and work environment perapen through a total ergonomic approach increased income by $15.78 \%$ [7]. This result is not much different from previous research that is ergonomic intervention research on work station design Wet blanket increase wage accepted by worker equal to 30,34\% [5].

When linked between productivity and income, income increases are directly proportional to productivity increases. This is reinforced by doing work load analysis, which if using ergonomic-oriented work method and working method is not ergonomically oriented the average work load is still classified as light work load with mean of pulse \pm 55 pulse / minute, so it is suggested to company to apply work oriented method ergonomics on sardine canning process. With simple, inexpensive and easy-to-implement improvements can improve the quality of health seen from decreased fatigue and musculoskeletal complaints, increase yield, productivity and income of the worker. 
Ni Luh Gede Aris Maytadewi Negara, Luh Made Indah Sri Handari Adiputra, and I Dewa Putu Sutjana

\section{CONCLUSIONS AND RECOMMENDATIONS}

From the results of the analysis and discussion, it can be concluded that:

1) Ergonomic oriented working method in the process of wiping cans of sardines increased worker productivity in PT.BMP Negara as much $34.43 \%$.

2) Ergonomic oriented working method in the process of wiping cans of sardines increased income of worker in PT.BMP Negara as much 31.51\%.

\section{SOURCES OF FUNDING}

This research received no specific grant from any funding agency in the public, commercial, or not-for-profit sectors.

\section{CONFLICT OF INTEREST}

The author have declared that no competing interests exist.

\section{ACKNOWLEDGMENT}

None.

\section{REFERENCES}

[1] Bali Maya Permai. Manual Hazard Analysis and Critical Control Point. Negara. 2015.

[2] Bali Maya Permai. Profil Bali Maya Negara. 2016. (cited 2016 May 04). Available From: http://www.bmpfood.com

[3] Nibel, B. And Freivalds, A. Method, Standars, and Work Design. McGraw-Hill. USA.1999.

[4] Manuaba, I.B.A. Aplikasi Ergonomi dengan Pendekatan Holistik Perlu, Demi Hasil yang Lebih Lestari dan Mampu Bersaing Makalah disampaikan dalam Temu Ilmiah dan Musyawarah Nasional Keselamatan dan Kesehatan Kerja Ergonomi. Jakarta. 2003.

[5] Setiawan, H. Desain Stasiun Kerja Blanket Basah Berbasis Ergonomi Meningkatkan Kualitas Hidup dan Produktivitas Pekerja di PT Sunan Rubber Palembang Provinsi Sumatra Selatan (Disertasi). Denpasar: Program Pascasarjana Universitas Udayana.2013.

[6] Sutjana, I.D.P. The Use of serrated sickle to incrase farmers's productivity Journal of Human Ergology. 2000.

[7] Suarbawa, I.K.G.J. Perbaikan Stasiun dan Lingkungan Kerja Perapen Melalui Pendekatan Ergonomi Total Meningkatkan Kualitas Produk, Produktivitas Dan Pendapatan Perajin Pada Proses Nguwad Trompong Di Desa Tihingan Klungkung. Disertasi. Program Pascasarjana Universitas Udayana Bali. 2016.

[8] Saputra, I K. D. A.; Purnawati, S.; Swamardika, I. B. A.; Adiputra, L. M. I. S. H.; Priambadi, I G. N.; Dinata, I M. K. Kursi Lantai dan Penataan Layout Meningkatkan Work Engagement dan Produktivitas Pekerja Pembuatan Atap Alang-Alang. Jurnal Ergonomi Indonesia (The Indonesian Journal of Ergonomic), Vol. 06 No. 01 Juni 2020 ISSN Print :1411951X, ISSN Online: 2503-1716. doi: https://doi.org/10.24843/JEI.2020.v06.i01.p01.

[9] Dewi, K. A. C.; Tirtayasa, K.; Handari, L. M. I. S. Sikap Kerja Lebih Ergonomis Menurunkan Gaya Kompresi Tulang Belakang dan Keluhan Muskuloskeletal serta Meningkatkan Produktivitas. Jurnal Ergonomi Indonesia (The Indonesian Journal of Ergonomics), Vol.05. No.02: Juli-Desember 2019 ISSN Print: 1411-951 X, ISSN Online: 2503-1716. doi: https://doi.org/10.24843/JEI.2019.v05.i02.p06.

[10] Sari, N. L. M. R. W.; Adiputra, L. M. I. S. H.; Muliarta, I M.; Adiputra, N.; Surata, I W.; Swamardika, I. B. A. Perbaikan Kondisi Kerja serta Pemberian McKenzie Exercise dan Peregangan Statis Memperbaiki Respon Fisiologis dan Meningkatkan Produktivitas Pekerja pada Industri Pembuatan Dupa di UD. Manik Galih Tabanan. Jurnal Ergonomi Indonesia (The Indonesian Journal of Ergonomic), Vol. 05 No.01 Tahun 2019 ISSN Print: 1411-951 X, ISSN Online: 2503-1716. doi: https://doi.org/10.24843/JEI.2019.v05.i01.p01. 